\title{
BACTERIAL FLORA OF THE TRACHOMATOUS CONJUNCTIVA*
}

\author{
BY
}

\author{
H. V. NEMA, A. BAL, K. NATH, AND B. R. SHUKLA $\dagger$
}

Trachoma Research Centre, A.M.U. Institute of Ophthalmology, Aligarh, India

TRACHOMA and bacterial conjunctivitis affect each other adversely. The superimposed infection not only prolongs the course of trachoma but predisposes the eye to frequent relapses. A number of reports (MacCallan, 1931; Wilson, 1935; Pagès, 1951; Poleff, 1951; Feigenbaum, Gurevitch, Landau, and Shamir, 1955; Akagi, Tsutsui, Nanba, Shimizu, and Nishikiori, 1958; Larmande and Longo, 1960) on the bacterial flora of trachomatous eyes have appeared in the world literature, but the only study made in India was that of the Trachoma Control Pilot Project (T.C.P.P.) in repeated monthly surveys in 1957-58. The diagnosis of the microorganisms in the course of the survey was made by smear examination only, which is inadequate. The present culture studies were, therefore, undertaken to identify the bacterial flora of the conjunctiva in various stages of trachoma.

\section{Material and Methods}

From November, 1962, to October, 1963, 379 trachomatous children from rural districts, whose ages ranged from 6 months to 14 years, were investigated. Trachoma Stages I, II, and III were found in 72, 88, and 117 cases respectively. 102 children had healed trachoma (Stage IV). Material from the lower fornix was inoculated on blood agar, Filde's, chocolate agar, Downie's blood tellurite, and McConkey's media. The organisms were identified by their morphology and biochemical properties (Table).

TABLE

DISTRIBUTION OF MICRO-ORGANISMS IN 379 CASES OF VARIOUS STAGES OF TRACHOMA

\begin{tabular}{|c|c|c|c|c|c|c|}
\hline \multirow{2}{*}{ Micro-organisms Isolated } & \multicolumn{4}{|c|}{ Stage of Trachoma } & \multirow{2}{*}{$\begin{array}{l}\text { Total } \\
\text { Cases }\end{array}$} & \multirow{2}{*}{$\begin{array}{l}\text { Percentage of Total } \\
\text { Positive Cases }\end{array}$} \\
\hline & I & II & III & IV & & \\
\hline $\begin{array}{l}\text { Staphylococcus albus (coagulase-negative) } \\
\text { Diphtheroids } \\
\text { Streptococcus viridans } \\
\text { Staphylococcus pyogenes (coagulase-positive) } \\
\text { Diplococcus pneumoniae } \\
\text { Neisseria catarrhalis } \\
\text { Haemophilus } \\
\text { Morax-Axenfeld diplobacilli } \\
\text { Other Gram-negative bacilli } \\
\text { Streptococcus haemolyticus } \\
\text { No organisms }\end{array}$ & $\begin{array}{r}51 \\
23 \\
11 \\
9 \\
6 \\
2 \\
5 \\
2 \\
0 \\
0 \\
7\end{array}$ & $\begin{array}{r}67 \\
31 \\
12 \\
9 \\
7 \\
5 \\
2 \\
3 \\
0 \\
1 \\
8\end{array}$ & $\begin{array}{r}92 \\
36 \\
15 \\
7 \\
7 \\
13 \\
3 \\
0 \\
2 \\
1 \\
8\end{array}$ & $\begin{array}{r}81 \\
34 \\
11 \\
10 \\
10 \\
3 \\
2 \\
1 \\
1 \\
0 \\
11\end{array}$ & $\begin{array}{r}291 \\
124 \\
49 \\
35 \\
30 \\
23 \\
12 \\
6 \\
3 \\
2 \\
34\end{array}$ & $\begin{array}{r}84.3 \\
35.9 \\
14.2 \\
10.1 \\
8.7 \\
6.7 \\
3.5 \\
1.8 \\
0.9 \\
0.6\end{array}$ \\
\hline Total Cases & 72 & 88 & 117 & 102 & 379 & - \\
\hline
\end{tabular}

\section{Observations and Discussion}

In trachomatous countries (Egypt, Tunis, and Morocco) an influence of seasonal

* Received for publication February 24, 1964.

† Officer-in-Charge, Trachoma Research Centre (I.C.M.R.), Aligarh. 
bacterial conjunctivitis on the course of trachoma has often been reported. Infection with Koch-Weeks' bacilli was frequently recognized in cases of trachoma, and the smear studies carried out by the Trachoma Control Pilot Project in India revealed that Koch-Weeks' bacilli and Morax-Axenfeld diplobacilli were the commonest organisms infecting the conjunctiva. Our results differ from those of the T.C.P.P. survey as well as from those of MacCallan (1931), Wilson (1955), Pagès (1951), Poleff (1951), and Larmande and Longo (1960). Out of 379 cases, only twelve organisms belonging to the Haemophilus group were isolated (Table). This low percentage of Haemophilus accords with the findings of Akagi and others (1958) in Japan. Feigenbaum and others (1955) also found $H$. influenzae and $H$. aegyptius in only a few cases.

The commonest bacterial species isolated from the trachomatous conjunctiva was Staphylococcus albus (191 out of 379). It was often associated with diphtheroids which were second only to Staph. albus in frequency.

The potential pathogenic micro-organisms isolated included Staph. pyogenes, Diplococcus pneumoniae, the Haemophilus group, Morax-Axenfeld diplobacilli, and Streptococcus haemolyticus. A few (Staph. pyogenes and Diplococcus pneumoniae) were isolated from asymptomatic cured cases of trachoma also. Moreover, it was apparent that the conjunctiva could harbour pathogenic organisms without any manifest signs of inflammation. This observation is in complete agreement with those of Tulsi Das, Sur, and Chaddah (1955) and Agarwal and Khosla (1963), who found similar organisms in healthy normal conjunctiva.

Contrary to the reports of Feigenbaum and others (1955), who found a higher frequency of bacteria in active trachoma than in healed cases, the bacterial flora in our series did not differ significantly (Table).

\section{Summary}

(1) Culture studies of the conjunctiva were carried out in 379 trachomatous cases.

(2) The commonest organisms isolated were Staphylococcus albus, diphtheroids, Streptococcus viridans, and Staphylococcus pyogenes. Organisms of the Haemophilus group were isolated in only twelve cases.

(3) No significant difference in bacterial flora was seen between cases of active and healed trachoma.

(4) In India the Haemophilus group of organisms seems to play only a small part in secondary infection in cases of trachoma.

The authors are grateful to the Indian Council of Medical Research for facilities to carry out this work, and to Messrs. K. C. Sharma and S. Masih for their technical assistance.

\section{REFERENCES}

Agarwal, L. P., and Khosla, P. K. (1963). Orient. Arch. Ophthal., 1, 145.

Axagi, G., TsutsuI, J., NANBa, T., Shimizu, H., and Nishikiori, H. (1958). Rev. int. Trachome, 35, 361.

Feigenbaum, A., Gurevitch, J., LANDaU, J., and Shamir, R. (1955). WHO Trachoma, 49.

LARMANDE, A., and LoNGo, A. M. (1960). Rev. int. Trachome, 37, 1.

MacCallan, A. F. (1931). Brit. J. Ophthal., 15, 369.

PAGÈs, R. (1951). Rev. int. Trachome, 28, 79.

POLEFF, L. (1951). Ibid., 28, 59.

T.C.P.P.-INDIA. Final Report (1956-59). S.E.A. Trachoma Rev., 1, 1961.

TUlSi DAS, SUR, M. L., and CHADDAH, M. R. (1955). Brit.J. Ophthal., 39, 21.

WILSON, R. P. (1935). "X Annual Report of the Giza Memorial Ophthalmic Laboratory, Cairo", p. 90. 